\begin{tabular}{|l|l|l||}
\hline \multicolumn{2}{|c|}{ PublisherInfo } \\
\hline \hline PublisherName & $:$ & BioMed Central \\
\hline \hline PublisherLocation & $:$ & London \\
\hline \hline PublisherImprintName & $:$ & BioMed Central \\
\hline \hline
\end{tabular}

\title{
Preinfarction angina protects against in-hospital adverse outcomes in the elderly
}

\begin{tabular}{||l|l|l||}
\hline \multicolumn{2}{|c||}{ ArticleInfo } \\
\hline \hline ArticleID & $:$ & 41 \\
\hline \hline ArticleDOI & $:$ & $10.1186 /$ cvm-2001-72057 \\
\hline \hline ArticleCitationID & $:$ & 72057 \\
\hline \hline ArticleSequenceNumber & $:$ & 20 \\
\hline \hline ArticleCategory & $:$ & Paper Report \\
\hline ArticleFirstPage & $:$ & 1 \\
\hline \hline ArticleLastPage & $:$ & 3 \\
\hline \hline & & RegistrationDate : 2001-10-18 \\
ArticleHistory & $:$ & Received $\quad: 2001-3-7$ \\
\hline \hline ArticleCopyright & $:$ & Biomed Central Ltd2001 \\
\hline \hline
\end{tabular}




\begin{tabular}{|l|l|l|}
\hline ArticleGrants & $:$ & \\
\hline \hline ArticleContext & $:$ & 1306322 \\
\hline
\end{tabular}

Joanna Lyford, ${ }^{\text {Aff1 }}$

Corresponding Affiliation: Aff1

Affl MedWire 7 mar 01, UK

Keywords

Myocardial infarction, preinfarction angina, unstable angina

\section{Context}

It is thought that angina experienced by elderly patients prior to a myocardial infarction (MI) may confer some benefits such as a lower incidence of adverse outcomes. This study aims to investigate the nature of the benefits of pre-infarction angina.

\section{Significant findings}

Elderly patients with a history of prodromal angina were at a lower risk of experiencing in-hospital death, the combined end point of death and heart failure $(6 \%$ versus $20.4 \%, P=0.02 ; 10 \%$ versus $23.7 \%, P=0.07)$ than those who didn't have angina. The absence of preinfarction angina increased the risk of depressed left ventricular function (ejection fraction $<40 \%$ ), which was observed in $44.8 \%$ of those who hadn't experienced angina compared with $26 \%$ of those who did. In addition, the angina free group experienced a greater incidence of arrhythmia (complete heart block and ventricular fibrillation) than those who had angina ( $16.1 \%$ versus $4 \%)$.

\section{Comments}

Pre-infarction angina may provide some protection against the subsequent ischemic burden on the atrioventricular node. A favorable outcome with prodromal angina one week prior to MI could be due to 
"ischemic preconditioning." Moreover, the authors note that "antecedent angina pectoris may help preserve myocardial integrity through the development of collateral circulation". As 2 weeks is thought necessary for collateral circulation to develop, it is possible that a delayed adaptive mechanism may play a part in favorable outcomes. In conclusion, the presence of pre-infarction angina may be an independent predictor of in-hospital death and heart failure in older patients.

\section{Methods}

A total of 290 consecutive elderly ( $>64$ years old, $n=143$ ) and adult ( $<65$ years old, $n=147$ ) patients were examined following their first MI.

\section{Additional information}

\section{References}

1. Navarro MJ, Gomez-Doblas JJ, Alonso-Briales J, Garcia JM, Gomez G, Alcantara AG, RodriguezBailon I, Barrera A, Montiel A, Caliani JS, de Teresa E: Does angina the week before protect against first myocardial infarction in elderly patients?. Am J Cardiol. 2001, 87: 11-15.

This PDF file was created after publication. 